\title{
PELAKSANAAN PROSES PEMBELAJARAN DIKELAS DENGAN STRATEGI LESSON STUDY BAGI GURU SMP NEGERI 5 KETAPANG
}

\author{
Rosita \\ Kepala SMP Negeri 5 Ketapang \\ Email: rositaamin9@gmail.com
}

\begin{abstract}
Abstrak
Pelaksanaan strategi lesson study dalam meningkatkan kemampuan guru dan peningkatan kualitas pembelajaran peserta didik di Sekolah Menengah Pertama Negeri 5 Ketapang. Tujuan penelitian Makalah ini adalah : untuk melihat proses pelaksanaan pembelajaran dikelas dengan strategi lesson study dalam memperbaiki kemampuan guru untuk menerapkan proses belajar mengajar yang aktif dan kreatif di SMP Negeri 5 Ketapang serta untuk mengetahui peningkatan kualitas pembelajaran peserta didik dalam pelaksanaan strategi lesson study di SMP Negeri 5 Ketapan. Pada kegiatan strategi lesson study yang dilaksanakan pada 4 mata pelajaran didapat kan hasil yang berbeda-beda dari setiap pertemuan dan pengajaran. Hasil yang didapat adalah yaitu terjadinya peningkatan aktifitas belajar siswa hal ini dikarenakan guru yang mengikuti lesson study bisa mengembangkan perangkat pembelajaran dengan maksimal dengan dibantunya tim observer yang sebagai tim penilai pada saat proses pembelajaran berlangsung. Dengan demikian pelaksanaan kegiatan strategi lesson study bisa meningkatkan kualitas guru dalam proses pembelajaran dan meningkatkan kualitas pembelajaran peserta didik dengan secara maksimal.
\end{abstract}

Kata Kunci: Pelaksanaan, Proses Pembelajaran, Strategi Lesson Study.

\section{PENDAHULUAN}

Pendidikan merupakan sarana penting untuk meningkatkan kualitas sumber daya manusia dalam menjamin keberlangsungan pembangunan suatu bangsa. Peningkatan kualitas SDM jauh lebih mendesak untuk segera direalisasikan terutama dalam menghadapi era persaingan global. Oleh karena itu peningkatan kualitas SDM sejak dini merupakan hal penting yang harus dipikirkan secara sungguh-sungguh. Jika pendidikan merupakan salah satu instrumen utama pengembangan SDM, tenaga pendidik dalam hal ini guru sebagai salah satu unsur yang berperan penting di dalamnya, memiliki tanggung jawab untuk mengembangkan tugas dan mengatasi segala permasalahan yang muncul. Guru merupakan komponen yang sangat menentukan dalam implementasi proses pembelajaran di dalam kelas sebagai unsur mikro dari suatu keberhasilan pendidikan. Tentu saja keberhasilan implementasi suatu strategi pembelajaran di dalam kelas tergantung pada kepiawaian guru dalam menggunakan metode dan strategi pembelajaran tersebut.

Pada hakikatnya pendidikan merupakan usaha sadar yang dilakukan seseorang terhadap orang lain agar memiliki pengetahuan dan keterampilan. Proses pendidikan selalu terjadi perubahan tingkah laku, bukan hanya perubahan yang diharapkan meliputi seluruh aspek-aspek pendidikan seperti, aspek kognitif, afektif, dan psikomotorik. Salah satu faktor penghambatnya pencapaian hasil belajar dan motivasi belajar peserta didik didasarkan pada kegiatan belajar mengajar yang telah guru berikan selama proses belajar mengajar dikelas. Kegiatan belajar mengajar yang dilakukan oleh guru didasarkan pada perangkat pembelajaran yang telah dibuat 
salah satu pendukung keberhasilan dalam mengajar ialah pemilihan metode dan model yang menimbulkan dan menumbuhkan keaktifan peserta didik untuk belajar lebih semangat dalam belajar.

Dilihat dari hasil supervisi yang dilakukan oleh kepala sekolah di SMP Negeri 5 Ketapang didapat hasil memaparkan bahwa masih ada sebagian guru yang melakukan proses pembelajaran yang secara tradisional sehingga berdampak bagi peserta didik dalam mecapai hasil belajar dan mengembangkan kreatifitas hanya secara terbatas saja. Pada era pendidikan sekarang guru harusnya dituntut untuk lebih kreatif dalam memilih dan menerapkan metode pembelajaran yang kreatif, tidak hanya membebani peserta didik konsep hapalan saja, akibatnya kreatifitas individual terutama peserta didik menjadi tumpul. Untuk itu perlu dilakukan Penelitian Makalah yang menuntut pemahaman peserta didik terhadap materi dengan membawanya seolah-olah berada dalam keadaan nyata.

Hal ini menuntut kreasi seorang guru dalam menciptakan hal-hal baru dalam pengajarannya melalui pelaksanaan proses pembelajaran dikelas dengan strategi lesson study yang melibatkan peserta didik aktif dalam belajar, baik secara mental maupun sosial yang melibatkan kemampuan mengumpulkan informasi, mengasoisiasi dan menyajikan dengan penuh percaya diri. Kendala lain dalam aktifitas belajar- mengajar yakni : (1) peserta didik masih kurang percaya diri untuk mengungkapkan gagasan, (2) peserta didik sulit memilih kata dan tampak ragu- ragu dalam berbicara, (3) motivasi ekstern jarang diberikan guru, sehingga ketika pelajaran selasai kurang memiliki kesan yang berarti pada siswa. (4) guru lebih banyak menjelaskan teori tentang berbicara, tetapi praktiknya jarang dilakukan. Berbagai problem yang ditemukan di kelas membutuhkan sebuah inovasi untuk mengatasinya, salas satunya dengan menerapkan pelaksanaan proses pembelajaran dikelas dengan strategi lesson study.
Berdasarkan uraian diatas peneliti tertarik untuk mengadakan penelitian yang akan menguji apakah melalui pelaksanaan proses pembelajaran dikelas dengan strategi lesson study dapat memperbaiki kemampuan guru dalam menerapkan proses belajar mengajar yang aktif dan kreatif di SMP Negeri 5 Ketapang.

Strategi Lesson Study. Lesson study mengkaji pembelajaran melalui perencanaan dan observasi bersama, yang bertujuan untuk memotivasi peserta didik aktif belajar mandiri. Pelaksanaan lesson study memberikan hasil yang memuaskan, ditunjukkan dengan nilai rata-rata siswa mengalami perubahan yang signifikan setelah dilakukan kegiatan tersebut. Banyak negara ingin mempelajari secara mendalam tentang kegiatan lesson study termasuk negara Indonesia. Lesson study mulai berkembang di Indonesia pada bulan Oktober 1998 dilaksakan oleh tiga perguruan tinggi negeri yaitu UPI Bandung, Universitas Negeri Yogyakarta dan Universitas Negeri Malang. Ketiga perguruan tinggi bekerjasama dengan JICA (Japan International Coorporation Agency) untuk mengadakan pelatihan lesson study bagi guru dan calon guru Indonesia. Tujuan diadakan kegiatan lesson study adalah untuk meningkatkan mutu pendidikan di Indonesia. Diharapkan dari kegiatan lesson study dapat meningkatkan semangat guru untuk terus berkembang dan berinovasi dalam menciptakan suasana pembelajaran yang menyenangkan dan tidak membosankan. (Davis, 2003).

Lesson study adalah salah satu bentuk kegiatan pengembangan profesional guru dengan ciri guru membuka pelajaran dan guru sejawat lain sebagai observer, sehingga memungkinkan guru-guru dapat membagi pengalaman pembelajaran dengan sejawatnya. Sedangkan menurut Riandi (Counterpart IMSTEP-JICA), lesson study adalah model pembinaan profesionalisme guru melalui semangat kesejawatan (collegiality) yang secara bersama-sama 
berusaha meningkatkan kualitas pembelajaran. lesson study adalah sebuah studi kasus tentang pendekatan orang jepang untuk meningkatkan pengajaran melalui pengembangan guru berbasis sekolah. Berdasarkan beberapa pengertian tersebut, dapat disimpulkan bahwa lesson study adalah suatu kegiatan untuk pembinaan profesionalisme guru bersama rekan sejawatnya (collegiality) untuk meningkatkan kualitas pembelajaran. (Davis, 2003).

Beberapa manfaat dari penerapan lesson study, antara lain : (1) mengurangi keterasingan guru dan komunitasnya dalam perencanaan, pelaksanaan serta perbaikan pembelajaran; (2) membantu guru untuk mengobservasi dan mengkritisi pembelajaran; (3) memperdalam pemahaman guru tentang materi pelajaran, cakupan dan urutan kurikulum; (4) menciptakan terjadinya pertukaran pemahaman tentang cara berpikir dan belajar siswa; (5) meningkatkan kolaborasi pada sesama guru dalam pembelajaran; (6) meningkatkan mutu pendidik dan mutu pembelajaran; (7) guru memiliki banyak kesempatan untuk membuat ide-ide pendidikan dalam praktik pembelajaran yang bermakna; (8) perbaikan praktik pembelajaran di kelas. Guru dapat mengambil manfaat tersebut dengan melakukan lesson study secara berkelanjutan dan bersiklus. Pola kegiatan lesson study bersiklus yang terdiri atas perencanaan (Plan), pelaksanaan (Do) dan refleksi (See). Setelah refleksi dapat kembali ke perencanaan lagi untuk tindakan lebih lanjut. Bentuk pelaksanaan kegiatan lesson study bersiklus seperti tampak dalam gambar berikut (Hinduan, A.2005):

Tahap Do (Perencanaan). Para guru yang bergabung dalam kelompok lesson study (kelompok LS) berkolaborasi menyusun Rencana Pelaksanaan Pembelajaran (RPP) yang berpusat pada siswa. Perencanaan diawali dengan menganalisis kebutuhan dan masalah yang dihadapi dalam pembelajaran seperti tentang kompetensi dasar, kekurangan fasilitas, kondisi siswa dan sebagainya. Kesimpulan dari hasil analisis akan menjadi bahan pertimbangan dalam menyusun RPP, sehingga menjadi sebuah perencanaan yang sangat matang.

Tahap Do (Pelaksanaan). Pada tahap pelaksanaan, kelompok LS menjalankan pembelajaran yang sesuai dengan RPP yang telah disusun bersama. Kelompok LS dibagi menjadi dua tugas yaitu satu anggota berperan sebagai guru model dan anggota yang lain sebagai obsever. Tugas dari guru model adalah mempraktekkan RPP yang disusun. Sedangkan, guru observer mencatat semua hal yang diamatinya mulai dari kesesuaian kegiatan pembelajaran dengan RPP, aktivitas guru, aktivitas siswa dan keadaan kelas.

Tahap See (Refleksi). Tujuan refleksi adalah untuk menemukan kelebihan dan kekurangan pelaksanaan pembelajaran. Kegiatan diawali dengan penyampaian kesan dari guru model, selanjutnya penyampaian hasil pengamatan oleh guru observer. Tahap ini adalah tahap yang sangat penting karena upaya perbaikan untuk proses pembelajaran selanjutnya tergantung dari ketajaman dan kejelian para guru observer mengamati kegiatan pembelajaran. Hasil observasi yang beragam dapat memungkinkan terjadinya pertukaran pengetahuan secara produktif sehingga dapat diaplikasikan untuk pembelajaran selanjutnya.

Lesson study dan Pembinaan Profesionalisme Guru. Pembelajaran yang berkualitas sangat ditentukan oleh kualitas komponen pendukung pembelajaran. Komponen yang paling pokok dalam pembelajaran adalah guru. Guru memegang peran yang sangat strategis dalam usaha pencapaian keberhasilan pembelajaran. Dalam kaitan ini guru digambarkan sebagai manajer dalam pembelajaran, seperti yang dinyatakan Saito, E. (2004) bahwa berdasarkan sejumlah kegiatan yang 
harus dilakukan guru, telah menempatkan peran guru sebagai "manager of learning" yang berarti guru sangat menentukan dalam hal perencanaan, pelaksanaan dan penilaian produktivitas proses belajar memgajar. Kegiatan lesson study adalah model pembinaan profesionalisme guru melalui semangat kesejawatan (collegiality) yang secara bersama-sama berusaha meningkatkan kualitas pembelajaran. Dalam kegiatan lesson study, Kepala Sekolah memiliki peran yang sangat penting terutama dalam memfasilitasi kegiatan sekaligus melakukan peran supervisor-nya. Bentuk pembinaan (supervise) yang dilakukan melalui lesson study dapat menghilangkan kesan pengawasan (inspeksi) terhadap para guru, sehingga para guru akan lebih mudah menerima saran dan kritik dalam usaha perbaikan kualitas pembelajaran. Lesson study menerapkan pola kegiatan bersiklus.

Lesson study dapat diajadikan alternative dalam memecahkan permasalahan profesionalisme guru terutama yang menyangkut peran dan fungsi guru dalam melaksanakan pembelajaran. Adanya permasalahan berkaitan dengan persyaratan yang belum dapat dipenuhi oleh sejumlah guru yang berada di lapangan, dapat diatasi dengan program pembinaan profesionalisme guru. Program tersebut hendaknya dapat dilakukan secara berkesinambungan agar konsep right at the first time and every time dapat dicapai. Konsep tersebut akan mewujudkan sekali guru profesional untuk seterusnya professional yang terdiri dari perencanaan (plan), pelaksanaan (do) dan refleksi (see). Setelah refleksi dapat kembali ke perencanaan lagi untuk tindakan lebih lanjut. (Stigler, J. W., \& Hibert, J. (1999).

Keterkaitan Lesson Study dalam meningkatkan kualitas pembelajaran. Dalam setiap langkah kegiatan lesson study, guru memperoleh kesempatan untuk: (1) melakukan identifikasi masalah pembelajaran; (2) mengkaji pengalaman pembelajaran yang biasa dilakukan; (3) memilih alternatif model pembelajaran yang akan digunakan dan merancang rencana pembelajaran; (4) mengkaji kelebihan dan kekurangan alternatif model pembelajaran yang dipilih; (5) melaksanakan pembelajaran dan mengobservasi proses pembelajaran; (6) mengidentifikasi hal-hal penting yang terjadi dalam aktivitas belajar peserta didik di kelas; (7) melakukan refleksi secara bersama-sama atas hasil observasi kelas; serta (8) mengambil pelajaran berharga dari setiap proses yang dilakukan untuk kepentingan peningkatan kualitas proses dan hasil pembelajaran. Pada setiap langkah tersebut, guru berkesempatan belajar untuk mengidentifikasi masalah, mengkaji pengalaman, mengajukan alternatif, memilih dan membandingkan alternatif solusi. Keempat langkah tersebut merupakan komponen dari kemampuan berpikir reflektif. Dengan melakukan leeson study, guru akan mengembangkan kemampuan berpikir reflektif. Lesson study merupakan model pembinaan guru melalui pengkajian pembelajaran secara kolaboratif dan berkelanjutan berlandaskan prinsip-prinsip kolegalitas dan mutual learning (saling belajar) untuk membangun komunitas belajar. Dengan kata lain, peserta kegiatan lesson study tidak boleh merasa superior (merasa paling pintar) atau imperior (merasa rendah diri) tetapi semua peserta kegiatan lesson study harus diniatkan untuk saling belajar. Guru yang sudah paham atau memiliki ilmu lebih harus mau berbagi dengan guru lain yang belum paham, sebaliknya guru yang belum paham harus mau bertanya kepada guru yang sudah paham. (Widodo, Yeti Sumiati \& Cucu Stiawati. 2006).

Dalam melaksanakan lesson study diperlukan interaksi di antara guru yang terlibat sehingga terwujud suatu kerjasama. Dengan demikian, guru dapat mengembangkan keterampilan kooperatif melalui kegiatan lesson study. Berdasarkan 
penelitian yang dilakukan oleh Yuni Wibowo dan Paidi terhadap dosen Biologi Umum, kemampuan kooperatif dosen secara total maupun dalam aspek-aspek tertentu mengalami peningkatan. Ini sebagai indikasi bahwa kegiatan lesson sudy yang dilaksanakan memiliki peran yang baik untuk meningkatkan kerjasama guru. Melalui kegiatan ini terjadi komunikasi yang baik antara guru, sehingga masalah yang berkaitan dengan materi maupun proses pembelajaran dapat dibantu oleh guru yang lain. Selain itu, saat kegiatan refleksi secara tidak langsung rekan sejawat telah member masukan dari aspek materi maupun pedagogik untuk perbaikan pembelajaran.

\section{METODE PENELITIAN}

Metode penelitian merupakan salah satu faktor yang sangat penting dalam pelaksanaan penelitian. Berhasil tidaknya penelitian banyak tergantung pada tepatnya dalam memilih serta pengetrapan metode penelitian, sehingga dapat diperoleh penelitian yang dapat dipertanggung jawabkan.

Jenis peneliitan ini merupakan pnelitian tindakan (action research), dengan tahap sebagai berikut: (1) Workshop kepada guru-guru tentang lesson study, (2) Observasi pembelajaran yang dilakukan oleh salah seorang guru, (3) workshop pengembangan komponen pembelajaran (plaan), (4) Pelaksanaan open lesson dan refleksi (Do \& See), dan (5) Evaluasi kegiatan lesson study.

Data penelitian diambil dari rekaman pelaksanaan pembelajaran, hasil test dan wawancara. Proses pembelajaran tersebut juga akan direkam dengan menggunakan video kamera untuk keperluan analisis lebih lanjut. Setelah pelaksanaan KBM akan dilakukan diskusi multi arah anatara guru dengan para observer. Diskusi ini sesunguhnya merupakan kesempatan bagi guru dan peserta lainnya untuk melakukan refleksi terhadap kegiatan pembelajaran yang telah dilakukan.

Oleh karena itu diskusi tidak bersifat evaluatif, tetapi lebih ke arah konstruktif dan kolaboratif. Dilakukan juga wawancara yang bersifat informal dan dialogis antara peneliti dengan guru/calon guru. Pada saat wawancara rekaman video pembelajaran yang dilakukan oleh guru/calon guru tersebut akan diputar sehingga guru/calon guru bisa mengamati kelemahan dan kekurangan yang mereka lakukan selama pembelajaran. Wawancara juga diarahkan pada persepsi guru/calon guru terkait ide/pandangan yang mengarahkan mereka melak sanakan pembelajaran seperti yangtelah dilakukannya dan bagaimana meningkatkan pembelajaran. Selain itu juga akan digali informasi terkait manfaat yang dirasakan guru/calon guru terhadap lesson study. Penelitian ini bertempat di SMP Negeri 5 Ketapang.

Yang menjadi subjek penelitian adalah peserta didik di SMP Negeri 5 Ketapang. Dalam penelitian ini yang bertindak sebagai guru perilaku tindakan adalah penulis. Penelitian ini akan dilaksanakan pada semester Genap Tahun Pelajaran 2018/2019 (Januari, Maret, dan April 2019) dengan memilih guru di SMP Negeri 5 Ketapang sebagai responden.

Pada dasarnya penelitian ini mengkaji bagaimanakah kegiatan lesson study dapat dilakukan sehingga dapat meningkatkan kualitas pembelajaran di SMP Negeri 5 Ketapang. (1) Lembar observasi menjaring kompetensi pedagogik dan profesional yang dimunculkan guru selama proses pembelajaran. (2) Pedoman wawancara untuk menjaring pandangan guru mengikuti program lesson study serta mengenai lesson study itu sendiri. (3) Pedoman untuk menganalisis video pembelajaran.

Dengan pelaksanaan pembelajaran dikelas menggunakan strategi lesson study dalam proses pembelajaran akan membuka kesempatan seluasluasnya kepada peserta didik untuk ikut aktif dalam pembelajaran. Dengan demikian guru bertanggung jawab penuh dalam memantau peserta didik dalam proses belajar mengajar, maka indikator keberhasilan dengan pembelajaran dengan menggunakan strategi lesson study adalah 83\% peserta didik telah mencapai kriteria ketuntasan minimal (KKM) yaitu 75 sesuai dengan yang ditetapkan SMP Negeri 5 Ketapang.

\section{HASIL DAN PEMBAHASAN PENELITIAN Hasil Penelitian}

Data penelitian yang diperoleh adalah data observasi berupa pengamatan terhadap (1) observasi pembelajaran sebelum kegiatan lesson study, (2) perencanaan pembelajaran dalam open 
lesson study (Plan), dan (3) Pelaksanaan open lesson study.

Berdasarkan hasil observasi yang dilakukan dalam Tahapan I Observasi pembelajaran sebelum kegiatan lesson study. Sebelum peleksanaan kegiatan lesson study dilakukan di SMP Negeri 5 Ketapang terlebih dahulu dilakukan pengarahan tentang lesson study. Peserta lesson study adalah guru yang ada diSMP Negeri 5 Ketapang. Kegiatan pengarahan tentang strategi Lasson Study ini dilakukan diruangan guru yang dibimbing oleh kepala sekolah. Kegiatan pengarahan dan bimbingan diawali dengan penjelasan mekanisme dan teknis pelaksanaan lesson study, tujuan lesson study, sasaran dari kegiatan lesson study, tren pembelajaran masa kini. Dari kegiatan ini, diharapkan guru dan kepala sekolah memiliki wawasan yang memadai menganai lesson study, memiliki motivasi untuk meningkatkan kualitas pembelajaran dan profesionalitas guru, serta memiliki gambaran pelaksanaan lesson study yang akan dilakukan bersama-sama di masing-masing pelajaran. Kegiatan ini diakhiri dengan diskusi penyususnan draf rencana pembelajaran yang akan dilakukan dalam open lesson di masingmasing pelajaran. Dari lokakarya guru dalam penyiapan perangkat pembelajaran ini dihasilkan draf RPP, LKS, dan lembar penilaian pembelajaran. Draf perangkat rencana pembelajaran ini selanjutnya disempurnakan dalam lokakarya lanjutan di masing -masing mata pelajaran.

Sebelum pelaksanaan kegiatan lesson study ini dilakukan terlebih dahulu observasi pembelajaran di masing-masing guru mata pelajaran. Selain kegiatan pembelajaran diobserasi, juga kegiatan pembelajaran direkam sehingga diperoleh video pembelajaran. Hal ini dilakukan untuk mengetahui kondisi awal kegiatan pembelajarn yang biasa dilakukan guru di masingmasing sekolah. Dari hasil pengamatan pembelajaran dan analisis video diperoleh informasi bahwa kegiatan pembelajaran di setiap sekolah umumnya masih didominasi oleh kegiatan guru menjelaskan. Interaksi peserta didik dan guru umumnya masih lemah dan KBM umumnya masih diwarnai kegiatan guru menerangkan konsep dan memberikan latihan/tugas. Dalam kegiatan pembelajaran di kelas, beberapa guru mencoba menerapkan kegaiatn belajar kooperatif (kelompok). Hasil pengamatan menunjukkan bahwa kegiatan pembelajaran kelompok belum efektif ditinjau kinerja dan interaksi peserta didik dalam kelompok. Belum tampak peserta didik melakukan berbagi gagasan (sharing idea) dan peserta didik belajar dari sesama temannya. Kegiatan kelompok masih didominasi oleh peserta didik yang berkemampuan lebih di dalam kelompoknya. Dari segi waktu, pembelajaran kelompok tampak lebih menyita waktu.

Tahap II perencanaan pembelajaran dalam open lesson study (plan). Perencanaan pembelajaran strategi lesson study didiskusikan dalam kegiatan bmbingan. Penyusunan perangkat pembelajaran ini dilakukan guru secara berkelompok. Pembentukan kelompok dilakukan berdasarkan guru yang mengajar pada mata pelajaran yang sama. Dari diskusi disepakati bahwa pelajaran yang akan dilakukan dalam open lesson study adalah matematika, IPA, bahasa indonesia, dan bahasa inggris. Kegiatan diskusi kelompok diawali dengan peninjauan silabus sesuai dengan materi yang akan diberikan di masing-masing guru, kemudian penyusunan RPP, LKS, dan alat penilaian pembelajaran. Dari kegiatan kelompok ini diperoleh draf komponen pembelajaran untuk matematika, IPA, IPS, bahasa indonesia, dan bahasa inggris. Draf komponen pembelajaran ini selanjutnya direvisi dan dilengkapi oleh kelompok guru di masingmasing mata pelajaran.

Tahap III pelaksanaan open lesson study (Do). Adapun implementasi open lesson study dan refleksi yang telah dilakuakn keempat mata pelajaran adalah sebagai berikut. (1) kegiatan pembelajaran, dan (2) refleksi.

\section{Pembahasan \\ Observasi pembelajaran sebelum kegiatan lesson study}

Beberapa fase kegiatan yang dilakukan dalam lesson study, seperti perencanaan dan persiapan pembelajaran (plan), implementasi pembelajaran yang dilakukan dalam bentuk open lesson (do), dan refleksi pembelajaran (see) adalah merupakan rangkaian kegiatan yang biasa dilakukan oleh seorang guru dalam kesehariannya. Di balik itu semua ada hal lainnya yang tidak biasa dilakukan guru, yaitu 
bekerja secara kolaboratif untuk melakukan itu semua. Kekuatan dari kegiatan lesson study adalah bagaimana kegiatan yang biasa dilakukan guru itu dikaji, dielaborasi, dan dikembangkan sehingga semua potensi yang dimiliki dapat diberdayakan secara sinergis sehingga menghasilkan suatu kegiatan pembelajaran yang lebih berkualitas dari kegitan sebelumnya. Suatu kegiatan pembelajaran yang direncanakan dan disiapkan dengan seksama, pelaksanaannya dieveluasi dan direfleksi dengan ketulusan tekad, kejujuran, keterbukaan, dan dengan komitmen yang tinggi untuk melalukan suatu perubahan yang lebih baik, mennghasilkan suatu yang lebih baik menjadi bukan suatu yang mustahil.

Dari kegiatan lesson study ini ditunjukkan bahwa kemampuan guru dalam merencanakan dan melaksanakan pembelajaran berproses menjadi lebih baik sesuai dengan tuntutan kurikulum. Walaupun keberhasilan dari kegiatan ini belum diukur berdasarkan tes hasil belajar siswa, berdasarkan hasil observasi dan refleksi pembelajaran, secara proses kualitas kegiatan pembelajaran lebih baik dari kegiatan-kegiatan sebelum kegiatan ini dilakukan. Dengan demikian, asumsi yang bisa dirumuskan adalah bahwa hasil pembelajaran yang lebih baik akan diperoleh dari kegiatan pembelajaran yang lebih baik. Keberhasilan dari lesson study bukanlah prestasi seseorang dalam waktu sesaat, namun merupakan pencapaian hasil dari suatu proses kolaborasi banyak pihak terutama antar sesama guru, kepala sekolah, dan pihak lain yang memiliki kepentingan yang sama dalam meningkatkan kualitas pendidikan, yang dilakukan secara berkesinambungan. Kesungguhan tekad, keterbukaan, dan kebersamaan semua pihak yang berkolaborasi inilah yang akan menentukan kegiatan lesson study.

\section{Lesson study, kualitas pembelajaran, dan profesionalitas guru}

Seperti telah dikemukakan di atas bahwa kegiatan lesson study merupakan kegiatan kolektif dan dan dalam interval waktu yang cukup. Lesson study yang dilakukan dalam penelitian ini sangatlah singkat, yaitu hanya sekitar tiga bulan, sehingga dirasakan oleh kebanyakan partisipan, bahwa kegiatan ini terlalu sisngkat dan perlu dilanjutkan. Idealnya, kegiatan lesson study harus diprogramkan dengan baik berdasarkan permasalahan yang dihadapi, dengan indikator keberhasilan yang terukur secara akurat. Karena keterbatasan waktu ini, untuk mengukur keberhasilan kegiatan tidak dilakukan menggunakan instrumen tes, namun menggunakan asesmen proses. Berdasarkan evaluasi proses ini, hasil penelitian menunjukkan bahwa lesson study dirasakan sebagai kegiatan yang mengenai sasaran dalam meningkatkan kompetensi guru, khususnya kompetensi guru dalam merancang dan melaksanakan pembelajaran (kompetensi pedagogis) dan kompetensi guru dalam materi subjek (kompetensi professional).

Dalam diskusi terakhir yang dilakukan, seluruh partisipan bermaksud melanjutkan kegiatan lesson study ini dengan menjaga kebersamaan diantara mereka untuk menjadikan fenomena pembelajaran yang dilakukan di kelas sebagai lahan subur yang harus dipelajari, dikaji, dan dikembangkan secara berkelanjutan untuk mendapatkan proses dan hasil yang lebih baik secara terus menerus pula. Apabila kegiatan seperti ini dilanjutkan secara terus menerus, sesuai dengan uraian di atas, kompetensi guru akan terkembangkan terus, sehingga kualitas pembelajaran pun dengan sendirinya akan meningkat. Dengan demikian, dapat lesson study dapat dijadikan sebagai program dalam peningkatan profesionalitas guru.

\section{Peranan lesson study dalam peningkatan kualitas pembelajaran}

Seperti sudah dikemukakan di atas, bahwa dalam kegiatan lesson study ini dilakukan open lesson sebanyak empat kali, masing-masing satu kali pertemuan. Frekuensi open lesson yang telah dilakukan dirasakan kurang oleh semua guru, terutama guru model. Berdasarkan evaluasi kegiatan, motivasi guru dalam kegiatan lesson study ini dirasakan sangat tinggi. Pertama, kehadiran mereka dalam setiap kali pertemuan yang dilaksankan, baik dalam perencanaan ataupun dalam open lesson mencapai $100 \%$. Kedua, parisipasi guru dalam setiap kesempatan diskusi menunjukkan mereka sungguh-sungguh dalam melaksanakan kegiatan ini , terutama dalam mengemukakan pengalaman, tanggapan, dan masukan/saran, serta mengajukan pertanyaan apabila dihadapkan pada hal-hal yang belum jelas atau kurang 
mengerti.Ketiga, keseriusan mereka dalam mempersiapkan dan melaksanakan open lesson .Kegiatan pembelajaran yang secara bersamasama diamati, dianalisis, dan dibahas oleh tim, dipersiapkan dengan menampilkan segenap potensi yang mereka miliki, sehingga kepala sekolah pun berkomentar akan sulitnya melaksanakan pembelajaran seperti yang telah dilakukan dalam open lesson. Namun, apabila hal itu dilakukan terus oleh guru, tampaknya kita tidak akan ketinggalan terus, bahkan pada gilirannya nanti kita akan menjadi yang terbaik. Para guru berpendapat bahwa kegiatan lesson study seperti ini sebenarnya harus dilakukan terus-menerus.

Hal seperti ini yang benar-benar diperlukan oleh guru, bukan kegiatan seperti pelatihan-pelatihan yang tidak ada tindak lanjutnya. Kegiatan lesson study dirasakan oleh para guru sebagai kegiatan yang benar-benar dirasakan manfaatnya. Dalam lesson study, kegiatan kolaboratif yang dilakukan guru mulai dalam perencanaan pembelajan. Rencana pembelajaran disusun secara bersama dengan memperhatikan potensi yang dimiliki, kekurangan yang ada, konteks atau tema yang tepat, media, bahan, scenario/alur pembelajaran, serta upaya-upaya agar pembelajaran dapat berlangsung secara efektif dan efesien. Penyusunan dan pengkajian rencana pembelajaran seperti ini jarang atau bahkan tidak pernah mereka dilakukansebelumnya. Kegiatan pengkajian seperti ini yang akan membangun kompetensi guru dalam merancang pelaksanaan pembelajaran. Dari rancangan pembelajaran yang sudah disusun dan dibahas secara kolaboratif, dalam kegiatanlesson study

\section{SIMPULAN DAN SARAN Simpulan}

Berdasarkan analisis data dari hasil penelitian yang telah peneliti paparkan di atas, maka peneliti dapat memberikan kesimpulan sebagai berikut. (1) kemampuan guru dalam merencankan dan melaksanakan pembelajaran. dalam strategi lesson study yang telah dilakukan guru memiliki komitmen yang tinggi, terbuka (open-minded), selalu berupaya untuk memperbaiki diri sendiri secara terus menerus, dan mampu bekerja kolaboratif dengan semua pihak yang terlibat dalam kegiatan lesson study sehingga dapat meningkatkan kemampuan guru dalam pelaksanaan pembelajaran dilakukan melalui open lesson. Dalam kegiatan open lesson salah seorang guru harus menjadi guru model dan melakukan implementasi pembelajaran sesuai dengan rencana yang sudah disusun bersama sama. Semua partisipanlesson study akan bertindak sebagai observer dalam kegiatan open lesson. Hal ini yang mendorong guru model untuk melaksanakan pembelajaran sebaik-baiknya.Tahap berikutnya yang harus dilakukan dalam kegiatanlesson study adalah refleksi.

Dalam bagian ini kegiatan pembelajaran yang telah dilakukan secara terbuka ini akan didiskusikan kekuatannnya, kelemahannya, hal hal yang semestinya dilakukan, hal-hal tidak semestinya dilakukan, saran-saran, dan hal lainnya berkaitan dengan pembelajaran yang telah dan atau yang akan dilakukan. Kesiapan guru model dalam melakukan evaluasi diri, menerima masukan, saran, atau kritik, sangatlah diperlukan oleh seorang guru partisipan lesson study .Dari keseluruhan kegiatan lesson study yang telah dilakukan dapat dikemukakan bahwa semua partisipan mengikuti kegiatan dengan serius dan menunjukkan dedikasi yang tiggi dalam melakukan seluruh kegiatanlesson study. Secara kualitatif kualitas proses pembelajaran yang dilakukan guru lebih baik daripada kualitas proses pembelajaran sebelum tindakanlesson study ini dilakukan. Hasil analisis video pembelajaran sebelumlesson study dilakukan dan ketikalesson study dilakukan berubah secara drastis, terutama dalam hal aktivitas peserta didik belajar, pengajuan pertannyaan guru dan peserta didik, respon/tanggapan peserta didik serta interaksi siswa-guru dan siswa-siswa.

mengembangkan proses pembelajaran. Keberhasilan dari lesson study bukanlah prestasi seorang guru atau kepala sekolah, namun merupakan pencapaian hasil dari suatu proses kolaborasi banyak pihak terutama antar sesama guru, kepala sekolah, dan pihak lain yang memiliki kepentingan yang sama dalam meningkatkan kualitas pendidikan, yang harus dilakukan secara berkesinambungan. (2) Dengan diterapkannya strategi lesson study dapat meningkatkan kualitas pembelajaran peserta didik hal ini didasarkan pada tercapainya kemampuan guru dalam menerapkan strategi lesson study yang sudah dilakukan dengan berbagai guru. 


\section{Saran}

Berkenaan dengan hasil penelitian dan pendapat dari para ahli pendidikan, peneliti menyampaikan saran-saran sebagai berikut. (1) Diharapkan kepada guru untuk selalu aktif mencari terobosan-terobosan baru, dalam upaya meningkatkan inovasi pembelajarannya, baik mengenai bahan, metode dan media yang dipergunakan yang sesuai dengan kondisi peserta didik dan guru dan dianggap mampu meningkatkan kreatifitas belajar peserta didiksehingga akan mampu meningkatkan prestasi belajar peserta didik. (2) Agar kegiatan lesson study dapat terlaksana dengan optimal, pihak sekolah harus mendukung upaya-upaya yang dilakukan guru dalam melakukan inovasi dan mampu mensinergikan semua komponen yang ada dan yang dilibatkan dalam kegiatan lesson study. (3) Diharapkan kepada peneliti yang lain untuk mencoba meneruskan penelitian ini dengan menguji cobakan suatu pendekatan dan metode yang lain yang dianggap mampu meningkatkan pengetahuan, pemahaman dan daya pikir siswa.

\section{DAFTAR PUSTAKA}

Davis, K. S. (2003). "Change is hard": What science are telling us about reform dan teacher learning of innovative practises. Science and Education, 87(1), 3-30.

Fraenkel, J. R., \& Wallen, N. E. (1990). How to design and evaluate research in education. San Francisco: Mc. Graw -Hill Pub. Co
Hinduan, A. A. (2005). Meningkatkan Profesionalisme Guru IPA di Sekolah. Makalah disajikan dalam seminar nasional pendidikan IPA II,. Bandung, 23 Juli 2005

Mellado, V. (1998). The classroom practise of preservice teacher and their cinception of teaching and learning. Science education, 82, 197-214

Oser, F., \& Patry, J. L. (1990). Choreographien Unterrichtlichen Lernens: Basismodelle des unterrichts [Choreographies of teaching and learning: Basic models of teaching]. Freiburg: Paedagogisches Institut der Universitaet Freiburg

Rustaman, N., Widodo, A., Anggraeni, S. Junaengsih, N. (2005). Evaluasi Pelaksanaan Kegiatan Piloting Biologi. FPMIPA UPI: Tidak diterbitkan.

Saito, E. (2004). Indonesianlesson study in practice: case study of IMSTEP. Paper disajikan dalam workshop bagi guru-guru Matematika dan sains. Bandung.

Stigler, J. W., \& Hibert, J. (1999). The Teaching Gap : Best Ideas from The World's Teachers for Improving Education in the Classroom. New York: the free Press

Widodo, Yeti Sumiati \& Cucu Stiawati. (2006). Peningkatan Kemampuan Murid SD Untuk Mengajukan Pertanyaan Produktif. Jurnal Pendidikan dan Pembelajaran. (in print) 